MARCIN POLAKOWSKI

Instytut Politologii UMK

\title{
Dwie twarze konserwatyzmu. Uwagi na marginesie tekstu Erika von Kuehnelt-Leddihna
}

Erik von Kuehnelt-Leddihn należy niewątpliwie do grona najbardziej zna-

Enych myślicieli i popularyzatorów idei prawicy XX wieku¹. Ten wywodzący się z Austrii pisarz, erudyta i podróżnik, swymi błyskotliwymi komentarzami i artykułami oraz gawędziarskim, publicystycznym talentem starał się nie tylko przybliżyć czytelnikowi najważniejsze idee prawicy, co czynił z lekkością i niespotykaną kompetencją, lecz również sam starał się zaprezentować własne stanowisko intelektualne, często idące wbrew odruchowym nawykom środowisk konserwatywnych czy liberalnych. Było to nie tylko pokłosiem temperamentu, inteligencji, wszechstronności zainteresowań Kuehnelt-Leddihna, lecz przede wszystkim oryginalności jego umysłu. Ten habsburski monarchista konsekwentnie bronił się przed zakwalifikowaniem do

Prace Kuehnelt-Leddihna od niedawna są ochoczo publikowane w języku polskim. Zob. E. von Kuehnelt-Leddihn, Ślepy tor: ideologia i polityka lewicy 1789-1984, przeł. M. Gawlik, Sadków 2007, ss. 675; Tenże, Przeciwko duchowi czasu, przeł. T. Gabiś, Sadków 2008, ss. 131; Tenże, Demokracja - opium dla ludu?, przeł. M. Gawlik, Łódź-Wrocław 2008, ss. 143; Wcześniej, nie licząc jednej powieści politycznej, wydanej w języku polskim już w roku 1937 (Tenże, Jezuici, burżuje, bolszewicy, przeł. J. Bross, Poznań 1937, s. 480), a wznowionej niedawno (Sadków 2008, s. 329), jego teksty były publikowane głównie w „Stańczyku” i „Pro Fide Rege et Lege”. Jeśli chodzi o omówienia jego postaci należy wymienić m. in.: T. Gabiś, Eryk von Kuehnelt-Leddihn: człowiek i dzieło, w: „Stańczyk”, nr 14, 1991; M. J. Chodakiewicz, Żywot prawego człowieka, w: „Templum”, nr 1, 2001, dostępne: http://templum.nazwa.pl/archiwum/tn1/9.html [9.11.2008]; J. Bartyzel, T. Mysłek, w: Naród i Rzesza w oczach tradycjonalisty, w: „Polityka Polska”, nr 12, 1989. 
określonego nurtu myślenia o polityce, uciekał nawet przed mianem konserwatysty. Formułując gruntowną krytykę zjawisk takich jak demokracja czy totalitaryzm, a ściślej rzecz biorąc większości cech myślenia lewicowe$\mathrm{go}^{2}$, których owe dwie formy, mimo wszystkich różnic, miały być manifestacją, sam siebie nazywał ,skrajnie prawicowym katolickim konserwatywnym arcyliberałem". Widział siebie jako zachowawcę wielkiej tradycji wolnościowej, będącej jednak sprzeczną - wbrew mniemaniom większości liberałów - $\mathrm{z}$ ideałem równości ${ }^{3}$, a manifestującą się w konserwatywnych porząadkach opartych na autorytecie Kościoła katolickiego i instytucji monarchii. Monarchia w jego pismach jawi się więc nie tylko jako jedyny moralny, prawdziwy i prawomocny ustrój społeczny, lecz zwyczajnie ustrój rozsądny, zgodny z wolnościową dyspozycją natury człowieka, którą pozwala mu ona najlepiej realizować i chronić. Czerpiąc więc ze zdroju Tradycji (i tradycji), nie cofał się Kuehnelt-Leddihn przed pochwałą myślicieli liberalnych nurtu arystokratycznego, niechętnych demokracji i nowożytnemu "buntowi mas”. W swych płomiennych, obficie okraszanych dowcipem tekstach proponował jednak pewien zestaw wyraźnych idei: wspomnianą wolność, hierarchię, ale i różnorodność. Miał to być jednak tylko pewien zestaw dóbr, w stronę których powinno zmierzać prawe społeczeństwo, nie cofając się przed ich twórczą syntezą (człowiek bowiem z natury jest twórczy), a nie zamknięty katalog lewicowych dyrektyw, koniecznych i możliwych do zaprowadzenia tu i teraz, w jednej, określonej z góry formie. Z tejże oryginalnej, granicznej perspektywy, próbując zdefiniować prawicę jako szeroki, lecz bynajmniej nie rozmyty ruch (jak to często kończy się w przypadku enigmatycznego nurtu konserwatywno-liberalnego), Kuehnelt-Leddihn dostrzegał również wiele paradoksów i wewnętrznych problemów różnych, niekiedy hermetycznych sposobów myślenia prawicowego i manifestowania prawicowości; wad niedostrzegalnych zawsze dla tych nazbyt identyfikujących się z jaskrawymi doktrynerskimi etykietami, niezbyt zaś przywiązanych do cnoty krytycznego myślenia.

Prezentowany poniżej tekst, dotyczący bezpośrednio jednego z najbardziej kontrowersyjnych wątków myśli konserwatywnej jest analizą właśnie tego rodzaju, typową dla omawianego pisarza, niezbyt liczącą się z utrwalonymi, wewnątrzformacyjnymi konwenansami, ograniczeniami czy lękami. Reinterpretujące poruszenie tematu ideologii jest niewątpliwie krokiem odważnym intelektualnie, gdyż stara się skorygować rozumienie poję-

Zob. E. von Kuehnelt-Leddihn, Leftism revisited: From de Sade and Marx to Hitler and Pol Pot, Washington 1990, s. 520.

3 Napięcie to zilustrował zresztą tytułem swojego opus magnum. Tenże, Liberty or Equality, London 1952, s. 395. 
cia, będącego głównym negatywnym punktem odniesienia dla konserwatyzmu czasów porewolucyjnych, pojmowanego - w mniejszym lub większym stopniu - jako doktryna polityczna. Jeśli bowiem uznać rewolucję, a w zasadzie leżącą u jej podstaw ideologię, za kluczowy element demonologii konserwatywnej, to Kuehnelt-Leddihn próbuje przynajmniej przeformułować część podstaw konserwatyzmu. Próba ta być może nie do końca spełnia oczekiwania czytelników, dotyka pewnych problemów i napięć, aniżeli je rozstrzyga, rozwiązuje czy uśmierza; meandrując poszukuje prawdy, ale niekiedy gubi trop w gąszczu figur retorycznych czy odniesień politycznych. Jednak - jak się wydaje - dotyczy rzeczywistego problemu myśli konserwatywnej, identyfikuje pewne kontradyktoryjne nurty, wewnętrzne konflikty i sprzeczności, w ten sposób nolens volens definiując jej tożsamość.

Pojęcie ideologii użyte po raz pierwszy w XVIII wieku samo w sobie było odpowiedzią na potrzebę znalezienia nowego określenia, mającego służyć opisowi, niezależnemu od dotychczasowych autorytetów. Namysł ten, wyrzekając się dawnych nawyków myślowych, dawnego języka i zakorzenionego w metafizyce klasycznej oglądu świata, siłą rzeczy postulował wyrwanie rzeczywistości z dotychczasowych torów ${ }^{4}$. Pojęciowe wyodrębnienie się ideologii, już w zamierzeniach jej pierwszych oddanych szermierzy, miato wyznaczać granicę pomiędzy „nienaukowymi” spekulacjami filozoficznymi czy teologicznymi, a nową "naukową” refleksją nad zbiorowością, poprzedzoną wcześniej pojawieniem się charakterystycznych dla nowożytności nurtów nominalizmu, kartezjanizmu, empiryzmu, sensualizmu czy wreszcie oświeceniowego racjonalizmu ${ }^{5}$. Konserwatyzm sprzeciwiający się tym radykalnym zmianom $\mathrm{w}$ dziedzinie postrzegania społeczeństwa bądź otwarcie wobec nich wrogi, siłą rzeczy wobec ideologii przyjmował postawę przynajmniej niechętną.

Takiemu, jednostronnemu postrzeganiu ideologii Kuehnelt-Leddihn w swym tekście oczywiście się sprzeciwia. Cezura oddzielająca pojęcie ideologii od tradycyjnych form refleksji wydaje mu się zbyt ostra, a jego wyraźnie pragmatyczno-praktyczne spojrzenie na rzeczywistość broni się przed nadawaniem ideologii charakteru wyłącznie negatywnego. Dzieje się tak z dwóch powodów.

Po pierwsze, funkcjonalne przekreślenie terminu ideologii, utrudnia w dużej mierze formułowanie jakichkolwiek wskazań, dotyczących nie tylko życia politycznego, lecz również osobistego. $\mathrm{W}$ dzisiejszym świecie zbyt da-

A. Wielomski, Ideologia, w: Encyklopedia polityczna, J. Bartyzel, B. Szlachta, A. Wielomski (red.), t. 1, Radom 2007, s. 127-130.

5 P. Jaroszyński, Ideologia, w: Encyklopedia „Białych Plam”, t. VIII, Radom 2002, s. 133-134. 
leko zaszło już bowiem utożsamienie pojęcia idei z ideologią, tak że przekreślając ideologię wyrzekamy się także idei, popadając w skrajny, niefunkcjonalny i niebezpieczny skrajny pragmatyzm. Kuehnelt-Leddihn zdaje się więc sugerować, że w świecie porewolucyjnym, w którym intelektualne podwaliny tradycyjnego porządku zostały zniszczone, a każda idea zrelatywizowana, poddana krytyce historycznej i rozpatrzona przez pryzmat perspektywiczności ludzkich przekonań, dogmatyczny antyideologizm jest przyjmowany jako wrogość do każdej idei, do idei jako takiej.

Po drugie, wspomniany radykalny antyideologizm $-\mathrm{z}$ co najmniej trzech powodów - jest pułapką nie mniejszą niż immanentystyczne lewicowe utopie, których ideologia była usystematyzowanym, politycznym wyrazem. Primo, konserwatyści potrzebują idei dla wyrażenia wiecznych prawd, którym są oddani. Secundo, oddanie się nowożytnej „metodzie prób i błędów” samo w sobie prowadzi do zagrożenia skrajnym sceptycyzmem, agnostycyzmem i irracjonalizmem, w ramach których jedynym uprawnionym działaniem jest zwierzęce wypróbowywanie wszystkiego. Tertio, człowiek jest zwierzęciem ideologicznym, więc odwrócenie się od ideologii i brak próby stworzenia ideologii prawicowej, zostawia wolne pole dla wszelkich lewicowców ochoczo korzystających z okazji. Znamienne dla Kuehnelt-Leddihna jest to, że w tym elemencie swojej rozprawy, trafia w czuły punkt konserwatywnego nurtu myślowego i to różnych jego odmian naraz. Przyjrzyjmy się im pokrótce bliżej.

Wspólne wszystkim konserwatystom przekonanie, iż dobrych porządków politycznych należy szukać w rzeczywistości ludzkiego doświadczenia przeszłości wydaje się zbyt wąskie, by konserwatyzm mógł utrzymać swą wewnętrzną spoistość i by różne ruchy, zupełnie od siebie różne i to na poziomie podstawowych stwierdzeń o świecie i człowieku, nie mogły najzupełniej zasadnie odwoływać się do tego konceptu. Pozornie podobne spojrzenie na rzeczywistość, jej pojmowanie i wartościowanie, na podstawie którego relacyjnie konserwatyzm odnosi się również do kategorii ideologii, odzwierciedla w gruncie rzeczy postawę filozoficzną każdego konserwatysty, która może być i bywa często dalece zróżnicowana. Nie jest zatem tak, iż konserwatyści muszą zgadzać się w kwestii oceny ideologii na gruncie wspólnych przekonań podstawowych. Tak oczywiście bywa, lecz równie często, o ile nie częściej, to raczej różne fundamenty filozoficzne niespodziewanie spotykają się w pewnym miejscu i przesądzają o podobieństwach, ale i często niedostrzegalnych różnicach. 
Choć $\mathrm{w}$ kwestii wewnętrznych podziałów w łonie konserwatyzmu, również w literaturze polskiej, powiedziano już bardzo wiele ${ }^{6}$, na potrzeby niniejszego komentarza przyjmijmy, że jeśli chodzi o stosunek do ideologii i uprzednią wobec niego podstawę ontologiczno-epistemologiczną, konserwatyści w czasach pierwszych triumfów ideologii i rewolucji utworzyli dwie orientacje, rzadko urzeczywistniane w postaci czystej, częściej jako mieszanina typu jednego i drugiego ${ }^{7}$.

Pierwszy typ orientacji konserwatywnej, wyznaczają zatem odwołujący się do idei kontrrewolucji tradycjonaliści (zazwyczaj z kręgu krajów romańskich $)^{8}$. Najpełniejsze doświadczenie rzeczywistości jest według nich ukryte w tradycji religijnej, zwracającej ludzi ku transcendencji oraz w klasycznej filozofii, będącej drogą ku prawdom wiecznym ${ }^{9}$. Refleksja myślicieli wyznających ten typ poglądów, zakorzeniona jest w filozofii chrześcijańskiej - najczęściej Augustyna lub Tomasza z Akwinu - a poprzez nią, rzadziej bezpośrednio, w klasycznej filozofii, próbującej odkryć stałą naturę rzeczy w świecie. Stałe podążanie ku odczytaniu tych uniwersaliów w porządku doczesnym, w świecie chrześcijańskim pochodzących od Boga, przekłada się na koncepcje filozofii i teologii politycznej, czerpiące wiele: $\mathrm{z}$ ewangelicznego stwierdzenia o podchodzeniu władzy od Boga, określonej interpretacji Pawłowego to katechon, filozofii św. Augustyna (antropologia augustyńska, rozróżnienie civitas Dei i civitas terrena, koncepcja imperium felix), gelazjańskiej teorii „Dwóch Mieczy” czy tomistycznej koncepcji rządzenia jako zaprowadzania ładu w życiu doczesnym z orientacją na wspólne dobro, odczytywane zgodnie ze wskazaniami prawa naturalnego, będącego z kolei partycypacją prawa wiecznego w porządku ludzkim. Na gruncie politycznym czerpanie z wymienionych wyżej źródeł przekłada się na ideę obrony lub restauracji tradycyjnej monarchii, jako najdoskonalszego wyrazu ładu chrześcijańskiego w porządku polityczno-wspólnotowym. Jeśli nawet ten ideał był z czasem modyfikowany (np. z uwagi na z rezerwą zresztą przyjmowany fakt wyłonienia się tożsamości narodowych) lub porzucany, to jedynie $z$ uwagi na

6 Zob. J. Bartyzel, Konserwatyzm, w: Encyklopedia „Białych Plam”, t. X, Radom 2003, s. 31-61; Tenże, Konserwatyzm i chrześcijańska demokracja - dwie drogi ku tej samej przepaści, w: „Nowe Państwo", nr 42; R. Legutko, Trzy konserwatyzmy, w: Tenże, Etyka absolutna i spoteczeństwo otwarte, Kraków 1994, s. 108-138; R. Skarzyński, Konserwatyzm: Zarys dziejów filozofii politycznej, Warszawa 1998, s. 9-52; A. Wielomski, Filozofia polityczna francuskiego tradycjonalizmu 1789-1830, Kraków 2003, s. 22-40.

Nie oznacza to jednak, iż możliwe jest dowolne mieszanie podstawowych założeń obu orientacji, jeśli chce się zachować elementarną spójność całości. Niektóre z tych założeń są bowiem sprzeczne i niemożliwe do pogodzenia w ramach jednego systemu.

8 J. Bartyzel, „Umierać, ale powoli!” O monarchistycznej $i$ katolickiej kontrrewolucji w krajach romańskich 1815-2000, Kraków 2002, rozproszone.

$9 \quad$ Por. R. Legutko, Trzy konserwatyzmy, w: Tenże, Etyka absolutna..., s. 111. 
wymogi realizmu politycznego, nigdy zaś sam w sobie, nigdy w takim stopniu, by zapoznać chrześcijański fundament monarchii jako „mimesis boskiego planu stworzenia świata" ${ }^{10}$.

To fundamentalne centrum jednego z nurtów konserwatywnego myślenia o polityce, który nazwać można tradycjonalizmem, jednoznacznie przesądziło o charakterze negatywnego stosunku do ideologii, jaki wyznawali myśliciele identyfikujący się z tymże nurtem. Ideologia była dla nich - najogólniej rzecz biorąc - heretycką „schizmą bytu”, pęknięciem w strukturze rzeczywistości, buntem wobec transcendencji i wobec tego, co wieczne. Była wyniesieniem do rangi bożków - ludzkich mniemań, platońskich doxai, przekształcających się w gnostycką nienawiść do rzeczywistości.

Tak pojęte myślenie ideologiczne jako rodzaj kalekiego nawyku myślowego, nie zważającego na Boga, prawdę i rzeczywistość, w oczach jego krytyków, zawiera w sobie defekty natury zarówno istotowej, jak i formalnej. Obie one są oczywiście niemożliwe do rozdzielenia, gdyż krytyka rewolucyjnej formy wypływa w tym przypadku z krytyki jej istoty. Fałszywy cel, jakim jest radykalna próba urzeczywistnienia nie-bytu, w tym przypadku determinuje środki, których nie sposób sprowadzić wyłącznie do kategorii gwałtownej zmiany polityczno-społecznej i potępienia jej kształtu, charakteru, wewnętrznej dynamiki. Wyrwana z kontekstu krytyka charakteru i sposobu przeprowadzenia zmian, podbudowana co najwyżej obroną określonych obyczajów, musi mieć dla tradycjonalistów, w najlepszym razie, jedynie drugorzędne znaczenie, nie dotyka bowiem sedna sensu przeobrażeń, jakie podczas rewolucji zachodzą. Same obyczaje społeczne, zmiecione przez rewolucyjną pożogę, mają bowiem znaczenie drugorzędne, jeśli mają być cenione jedynie przez wzgląd na ich swojskość, zakorzenienie czy swoistą funkcjonalność. Mają one wartość rudymentarną tylko w kontekście określonej i żadnej innej tradycji, w ramach której przyjmują taki, a nie inny kształt. Obyczaj jako taki nie jest na gruncie filozofii politycznej tradycjonalistów wartością samą w sobie.

Krytyka ideologii i wynikających z niej wydarzeń rewolucyjnych nie ma charakteru potępienia samej zmiany czy nawet szybkiej zmiany, w której - nie do końca uchwytne i określone - tradycyjne „coś” jest gubione. Oczywiście rzekome dobrodziejstwo szybkiej zmiany u wszystkich konserwatystów budzi co najmniej niedowierzanie, jednak na gruncie klasycznej osnowy teoretycznej zmiana władzy zastępująca złe porządki dobrymi jest w gruncie rzeczy korzystna, gdyż pomaga człowiekowi zjednoczyć się z prawdą, osiągnąć cel i szczęście wieczne, chrześcijańskie zbawienie. Jeśli

10 J. Bartyzel, Monarchia, w: Encyklopedia „Białych Plam”, t. XII, Radom 2003, s. 188. 
nawet próbować oddzielić formę rewolucji od jej istoty, to w oczach tradycjonalistów nie jest ona zła ze względu na swą dynamikę, lecz z uwagi na to, kto i przeciwko komu ją inicjuje. Bunt ludu przeciwko umiłowanej i czcigodnej instytucji monarchicznej władzy, uosabianej przez osobę króla jest więc zwyczajnym odwróceniem ról, wystawiającym wspólnotę na zagrożenie nieładem. Pytanie przeciwko czemu zmiana jest skierowana, automatycznie jednak naprowadza nas na jej cel, a więc nakazuje pytać dalej o jej istotę. Nieład ma tutaj bowiem zawsze nie tylko aspekt doczesny, ale i wieczny, nie jest tylko nieładem w ramach immanencji, ale nieładem duszy.

Druga postać ogólnie pojętego myślenia konserwatywnego o ideologii i rewolucji niechybnie związana jest z myślicielami, koncepcjami i tradycjami brytyjskimi ${ }^{11}$. Łączy się ona pośrednio z omówionym wcześniej nurtem tradycjonalistycznym, dzieli z nim również wiele intuicji i spostrzeżeń, jednak bezrefleksyjne klasyfikowanie ich pod tym samym mianem konserwatyzmu, nie wyczerpuje bynajmniej katalogu, a co ważniejsze charakteru podobieństw i różnic, jakie te dwie orientacje prezentują. Stwierdzenie krytycznego podejścia obu tendencji do pojęcia ideologii jest więc zdecydowanie niewystarczające i wydaje się pewne sprawy raczej zaciemniać, aniżeli rozjaśniać.

Konserwatyzm nurtu odmiennego od tradycjonalistycznego jako świadoma doktryna wyłonił się również jako reakcja na konkretne wydarzenia historyczne Rewolucji Francuskiej ${ }^{12}$. Rozwinięty później i określany czę-

11 Choć w ramach tej tradycji wymienia się również np. myślicieli francuskich, choćby Montaigne'a czy Tocqueville'a. Por. J. Kekes, The Examined Life, University Park 1992, s. 6276; B. Frohnen, Virtue and the Promise of Conservatism, Lawrence 1993, ss. 214.

12 E. Burke, Reflections on the Revolution in France, And on the Proceedings in Certain Societies in London Relative to that Event. In a Letter Intended to Have Been Sent to a Gentleman in Paris, London 1790. Wyd. pol. Rozważania o rewolucji we Francji: $i$ o debatach pewnych towarzystw londyńskich zwiazanych z tym wydarzeniem, wyrażone $w$ liście, który miał zostać wysłany do pewnego gentlemana w Paryżu, przeł. D. Lachowska, Kraków-Warszawa 1994, ss. 270. Kwestia zaliczenia Burke'a do konkretnego typu konserwatyzmu jest sprawą niezwykle sporną, biorąc pod uwagę również pewne zwroty ideowe, będące jego udziałem. Na poglądy Burke’a ogromny wpływ wywierała myśl przedstawicieli oświecenia szkockiego. Od Francisa Hutchesona czy Adama Smitha autor Rozważań czerpał wiele intuicji dotyczących estetyki, teorii moralności czy ekonomii. Od nich też wydawał się czerpać przychylność wobec stosowania metody historycznej w problematyce społecznej. Zob. R. Rydz, Edmund Burke na ścieżkach wolności, Poznań 2005, s. 119-123. W kwestii metafizycznego nastawienia Burke'a w literaturze można spotkać się z dwoma różnymi interpretacjami. Pierwsza mówi o przynależności Burke'a do tradycji liberalno-utylitarystycznej, droga sytuuje go w kręgu myślicieli nurtu klasycznej teorii prawa naturalnego. Pierwsi interpretują jego postawę jako antymetafizyczną, drudzy widzą prawo naturalne jako kamień węgielny jego metafizycznego nastawienia. J. L. Pappin III, The Metaphysics of Edmund Burke, New York 1993, s. XV. Por. B. Szlachta, Kontrrewolucja w imię obowiazywania prawa naturalnego? Uwagi na marginesie pew- 
stokroć mianem konserwatyzmu ewolucjonistycznego, nie do końca jednak odpowiadał analogicznym krytykom nurtu tradycjonalistycznego, swymi korzeniami sięgał zaś w nieco inne podglebie. Było ono samo w sobie znaczone silnymi wpływami myśli nowożytnej, w ramach której według romańskich reakcjonistów od dawna tkwił zasiew przewrotu, który dokonał się później. Oparcie tej orientacji na silnych filarach nominalizmu, empiryzmu, naturalizmu czy sensualizmu, na śladach pozostawionych przez Williama Ockhama, Thomasa Hobbesa, Adama Smitha czy - nade wszystko - Davida Hume'a ${ }^{13}$, naturalnie spychało na margines lub - w najlepszym razie - czyniło równorzędnymi inspiracje klasyczne $\mathrm{z}$ ich wyrazami filozoficzno-politycznymi, również zaistniałymi $\mathrm{w}$ ramach wyspiarskiej tradycji myślowej ${ }^{14}$. W toku rozwoju tego nurtu konserwatyzmu na drugi plan zepchnięte zostało absolutne pojęcie bytu i wynikającego z niego dobra, prawdy i piękna, zbudowanych na gruncie metafizyki klasycznej. Na pierwszy plan wysunęło się natomiast socjologizujące nastawienie badania zależności społecznych, poszukiwania dobra wewnątrz danej wspólnoty, w ramach jej historii, nigdy poza nią. Wyraża się ono w pojęciu rzeczywistości jako pewnej części doświadczenia ludzkiego określonego granicami kulturowo-cywilizacyjnymi, wyznaczającymi jej tożsamość, dynamikę, historię ${ }^{15}$.

Stąd, krytyka ideologii formułowana w ramach tej tradycji nierzadko skupia się na formie, jaką przyjmuje myślenie ideologiczne oraz wydarzenia rewolucyjne. Mamy więc do czynienia z odcięciem się od wszechogarniającego, technicznego, funkcjonalistycznego i mechanistycznego języka ideologii, próbującej zburzyć porządek stary i zbudować nowy, wyznaczyć człowiekowi miejsce $\mathrm{w}$ świecie, ująć życie ludzkie $\mathrm{w}$ wymiarze indywidualnym jak i zbiorowym w nazbyt racjonalistyczne formuły i łańcuchy sylogizmów, zaś nieprzezwyciężalne niedostatki człowieka przezwyciężyć za pomocą prostackich recept. Wydarzenie rewolucyjne wprawia zaś mechanizm ideologiczny w ruch, niszczy stare hierarchie, zwyczaje, zakorzenione we wspól-

nego sporu konserwatystów, w: Panorama myśli kontrrewolucyjnej. Praca zbiorowa, J. Bartyzel (red.), Pułtusk-Toruń 2007, s. 29-47.

13 Zob. np. M. Oakeshott, Hobbes on Civil Association, Indianapolis 1975, ss. 174; D.W. Livingston, Hume's Philosophy of Common Life, Chicago 1984, ss. 371.

14 Można tu wymienić: nawiązująca do grecko-klasycznego i chrześcijańskiego regimen commixtum monarchię prawa Jana z Salisbury i Sir Johna Fortescue, teologię polityczną Richarda Hookera, ideał absolutnej suwerenności monarchy wywodzącej się z nadania Bożego Roberta Filmera czy nawet - z pewnymi zastrzeżeniami - figurę króla-patrioty Henry'ego Bolingbroke'a. Zob. B. Szlachta, Monarchia prawa. Szkice z historii angielskiej myśli politycznej do końca epoki Plantagenetów, Kraków 2001, s. 81-131, 263-318; Tenże, Monarchia prawa? Angielska myśl polityczna doby Tudorów, Kraków 2008, s. 723; J. Bartyzel, Regimen Commixtum, dostępne: http://haggard.w.interia.pl/regimen.html [9.11.2008].

15 R. Legutko, Trzy konserwatyzmy, w: Tenże, Etyka absolutna..., s. 118-119. 
nocie rozumienie rzeczywistości, rezultaty wysiłków odwiecznej unii pokoleń. Wymyślony, abstrakcyjny projekt społeczny siłą rzeczy nie dotrzymuje kroku misterności, bogactwu i zawiłościom rzeczywistości społecznej, odczytywanej w perspektywie zgromadzonego doświadczenia przodków, jako taki jest więc wulgarny. Niekiedy jednak - i tutaj można napotkać już duże różnice zdań i dowolność w ramach opisywanego nurtu - wprowadzany bez zbędnego dogmatyzmu i zacietrzewienia, z roztropnością, ewolucyjnie i w pewnych tylko elementach może prowadzić do ulepszeń i innowacji.

W takiej perspektywie zachowawczość jest poczytywana jako pewna dyspozycja oswajająca życie zbiorowe. Nie ma jednak ambicji odkrycia i realizowania telosu życia we wspólnocie. Brak tego celu nie jest wszakże trwożliwą reakcją na czas zamętu, lecz raczej głębszą dyspozycją ontologiczną i epistemologiczną, wynikającą z częściowego przyjęcia światopoglądu nowożytnego obalającego gmach dawnej metafizyki, odczarowującego świat społeczny, ale wedle wielu nie odsłaniającego w zamian nic godnego uwagi. Krytyka ideologii prowadzona $\mathrm{z}$ takich pozycji była często dość mętna lub nieokreślona filozoficznie, w tym sensie bardziej empiryczna, że nie tyle odnosiła się do absolutów, ile raczej wychodziła od obserwacji społecznej, zastanego systemu wartości i moralności społecznej. Przyjmując aktualny język i poczucie historycyzmu, perspektywizmu czy relatywizmu, orientacja ta ewoluowała, a doprowadzając kolejne przesłanki do logicznych konkluzji, spowodowała wyodrębnienie się konserwatyzmu sceptycznego, negującego pojęcie prawdy absolutnej (lub przynajmniej stwierdzającego niemożność dotarcia do niej), konstatującego względność wartości bronionych instytucji i praktyk społecznych, a więc prowadzącego do zanegowania możliwości sformułowania jakiegokolwiek uniwersalnego projektu politycznego. Ewentualne świadome próby zbudowania koncepcji natury ludzkiej i działania człowieka są tutaj zapośredniczone przez doświadczenie nowożytności, czerpią wiele z nieklasycznych koncepcji metafizycznych, tworzą często dość dowolne koncepty, których elementem wspólnym jest niechęć do ideologii na poziomie indywidualnym i zbiorowym, jak i ostrożność wobec niemal wszystkich projektów politycznych. W tej relatywizującej perspektywie na zarzut nieuprawnionej arbitralności narażone są więc nawet koncepcje klasyczne, per se z konserwatystami kojarzone, gdyż jeśli nawet nie mają charakteru ideologicznego, same w sobie nie wyrażają niepoznawalnej (nieistniejącej?) przecież prawdy i są tak samo podatne na zagrożenie degeneracji w porządku społecznym czy nieprzystawalności do danych warunków. Wyrzeczenie się poszukiwania ponadfizycznej istoty rzeczy w świecie, zadania jej odkrycia i opisania a jednoczesne dostrzeżenie marności ideologicznych protez, prowadzi do zwrócenia się w stronę lokalnej tradycji, nie 
z afirmacją, lecz raczej rezygnacją. Jeśli paradoksalnie - mistrzowie podejrzeń byliby zadowoleni - każda propozycja zbiorowa może być poddana refleksji „radykalnie burzycielskiej”" ${ }^{16}$ i oskarżona o zarzut ideologiczności, pozostaje skupienie się na problemie ludzkiej podmiotowości, budowanie teorii konserwatywnej w oparciu i w odniesieniu do niej. Inspiracje klasyczne zachowywane są tutaj w formie szczątkowej, jako jedno $\mathrm{z}$ - już raczej wyschniętych - źródeł tradycji cywilizacji europejskiej, ale nie jako rzeczywisty wyznacznik tego co dobre, piękne czy prawdziwe w życiu osoby i tym bardziej wspólnoty.

Eric von Kuehnelt-Leddihn wyraźnie, choć nie całkiem ortodoksyjnie, skłania się ku pierwszej orientacji konserwatywnego myślenia o ideologii. Zdaje sobie jednak sprawę również z jej praktycznych niedostatków, z faktu, iż konserwatywne credo nie może być przekładane na doraźny program polityczny bez zapośredniczenia w nowożytnym sposobie przedstawiania działań, a więc i bez znaczących wewnętrznych korekt. Sam niejako zdaje się sugerować, iż dzisiejsze ideologie - te dobre i szlachetne - mogą i powinny czerpać z różnych źródeł. Kurczowe trzymanie się starych konceptów, nieprzystających do nowej sytuacji, nowych wyzwań, nowych oponentów, grozi tylko ich ośmieszeniem. Dziś żadna synteza ideologiczna nie przekracza granic wyobraźni, a życzliwi wyobraźni ludzie prawicy powinni zdawać sobie $\mathrm{z}$ tego sprawę lepiej niż ktokolwiek inny ${ }^{17}$. W przeciwnym razie grozi to popadnięciem w skostniałość, kojarzącą się Kuehnelt-Leddihnowi z myśleniem sceptycznym.

Jak się wydaje, kluczem do równowagi w tym zakresie jest dla austriackiego myśliciela chrześcijaństwo, bez którego jego myśl, przynajmniej wyrażona w przedstawionym artykule, nie może być zrozumiała. Człowiek został z jednej strony stworzony na podobieństwo Stwórcy (imago Dei), zatem jest do twórczości powołany i nie powinien popadać w obojętność i rezygnację, jeśli chodzi o walkę o wieczne ideały (jest przecież „stawającym się stworzeniem, przechodzi metanoię"), z drugiej zaś jego pycha jest miarkowana przez świadomość grzechu pierworodnego i „brzemię praojca Adama”, gdyż „nawet jeśli rozpacz jest możliwa do uniknięcia, to żal i smutek nie”.

16 Por. M. Oakeshott, Filozofia polityki, w: tenże, Wieża Babel i inne eseje, przeł. A. Lipszyc, Ł. Sommer, M. Szczubiałka, Warszawa 1999, s. 119-138.

17 Podkreślanie roli wyobraźni w konserwatywnym działaniu zbliża go z kolei do myślicieli pokroju Burke'a (którego nie sposób bezproblemowo ująć w jakiekolwiek typologie konserwatyzmów), Smitha czy Disraeli'ego. Zob. E. Burke, Dociekania filozoficzne o pochodzeniu naszych idei wzniosłości i piękna, przeł. P. Graff, Warszawa 1968, ss. 204. Por. G. Himmelfarb, The Moral Imagination: From Edmund Burke to Lionel Trilling, Chicago 2006, ss. 259. 
Rozdźwięk między dwiema opisanymi orientacjami myślenia konserwatywnego również według autora Liberty or Equality? jest więc ogromny. Wydaje się jednak, że choć konserwatyzm sceptyczny dalece różni się od tradycjonalizmu, bliższemu intuicyjnemu i potocznemu rozumieniu konserwatyzmu (co musi wiązać się również z dużymi rozbieżnościami w dziedzinie pojmowania religijności), to trudno go przypisać do jakiegokolwiek innego nurtu filozoficzno-politycznego czy - zwłaszcza na niższym poziomie doktrynalnego ${ }^{18}$. Nawet jeśli konsekwencją rozwoju tych nurtów są dwie radykalnie od siebie odmienne koncepcje podmiotu ${ }^{19}$, a podobne zapatrywania polityczne są dziś raczej incydentalne ${ }^{20}$, to mimo wszystko obie one wydają się przynależeć do jednej konserwatywnej rodziny. W rodzinie tej jednak, właśnie z uwagi na opisane pęknięcia, nie sposób uniknąć kłótni i swarów.

M A R C I N P O L A K O W S K I

18 Konserwatyzm sceptyczny, w XX wieku rozwijany choćby przez Michaela Oakeshotta, George'a Santayanę czy Johna Kekesa, według wielu może być zaliczany do rodziny liberalnych nurtów politycznych. $\mathrm{O}$ ile jednak jest wiele pytań czy ten typ konserwatyzmu rzeczywiście konserwatyzmem winien być nazywany, o tyle w ramach liberalizmu musiałby on stanowić nurt absolutnie peryferyjny i jeszcze bardziej wątpliwy. Por. W.J. Coats, Michael Oakeshott as Liberal Theorist, „Canadian Journal of Political Science”, Vol. 18, No. 4, 1985 ,

s. 773-787. P. Franco, Michael Oakeshott as Liberal Theorist, „Political Theory”, Vol. 18, No. 3, 1990, s. 411-436. J. Gray, Berlin, Oakeshott i Oświecenie, w: tegoż, Po liberalizmie: eseje wybrane, przeł. P. Maciejko, P. Rymarczyk, Warszawa 2001, s. 401-420.

19 Szczególnie pomocne jest tu dokonane $\mathrm{w}$ ramach refleksji nad wolnością wewnętrzną przez Ryszarda Legutkę rozróżnienie na "Ja" nieistniejące i metafizyczne. Pierwsze, przynależne konserwatystom sceptycznym („,konserwatyzm poczciwca”) to sytuacja braku „metafizyczne ugruntowanego podmiotu, który pozostawałby faktycznie tożsamy mimo wszystkich zmian, jakim podlega każdy byt”. Drugie, jest charakterystyczne dla koncepcji tradycjonalistów z ich wyraźnym określeniem natury ludzkiej, ujęciem jej w sposób hierarchiczny i założeniem, że człowiek realizuje się „poprzez identyfikację z tym, co ogólne”. Zob. R. Legutko, Traktat o wolności, Gdańsk 2007, s. 160-165, 203-208.

20 Np. z konceptu "Ja" nieistniejącego może wypływać również radykalizm rewolucjonisty (jeśli „zamiast «ja» poczciwego będziemy mieli «ja» radykalnie aktywne”), gdyż „harmonijne połączenie konserwatyzmu politycznego oraz sceptycyzmu poznawczego nie jest przecież wcale stabilne". Tamże, s. 165-166. 


\section{Abstract}

The article Two faces of conservatism. Notes in the margin of Eric von KuehneltLeddihn's text constitutes a certain commentary to the text of one of the most important thinkers and representatives of the rightist ideas in the $20^{\text {th }}$ century.

Eric von Kuehnelt-Leddihn was an intellectual who described himself as a defender of the western tradition of liberty embodied in the idea of monarchist rules against egalitarianism, mass culture and others unifying trends of the $20^{\text {th }}$ century. Political expressions of these trends were totalitarianism but also democracy.

In the text Utopies and ideologies. Another chapter in conservative demonology, Kuehnelt-Leddihn writes about aversion to ideology widely regarded in conservative thought. This sentiment, especially in the English-speaking world - often transforms into hate to any clear ideas, which, after all, in Kuehnelt-Leddihn opinion - is nothing else than another form of ideologism which the conservatists cannot be reproached for.

According to this text, the author briefly presents the main aspects of conservative attitude to ideology and distinguish two currents within it. The first one is deep-rooted in the classical way of thinking about political order, which is characteristic for ancient Greek philosophy of Plato and Aristotle and christian philosophy of Augustine or Aquinas. In this perspective, a concept of political order is immersed in the judgments of Good, Beauty and Truth, sought with reference to transcedence. In this view modern immanentist ideology is nothing else than "schism of being" and the revolution, being its practical embodiment, is only a consequence of the primal false. The second conservative orientation, popular especially in the English-speaking world, is much more modern in its intellectual roots, therefore it examines revolution in the light of historical experience of specific community, its customs and traditions. Revolutionary events are considered and condemned as they destroy historical order and functional habits of the particular society. This highly relativistic perspective resulted in a conclusion, which drives to the sceptical conservatism.

Both of these orientations seem to be strongly connected with the notion of conservatism. 